\title{
Conservation of Coral Reefs After the 1998 Global Bleaching Event
}

\author{
T. J. Goreau, R. L. Hayes, T. McClanahan \\ Conservation Biology, Vol. 14, No. 1, Feb., 2000
}

\section{Coral Bleaching and Sea Surface Temperature Anomalies}

Large-scale coral bleaching has happened repeatedly in the Pacific and Indian oceans and the Caribbean since 1982. Previously it was observed only on a small scale (Williams and Bunkley-Williams 1990; Jokiel \& Coles 1990; Glynn 1988, 1991; Goreau et al. 1993; Goreau \& Hayes 1994, 1995). The 1998 bleaching event was globally the most extensive such event recorded except in the Caribbean and Central Pacific where a comparison of year-byyear temperature and bleaching maps show that it was comparable with the largest previous events (T.G. et al., unpublished data). Global analyses of coral bleaching are rare, but critical to an understanding of the widespread ecological effect of bleaching events. We reviewed data, both published and unpublished, on the 1998 event and discuss the potential broad-scale implications for coral reef conservation.

Large-scale coral reef bleaching is triggered by positive sea surface temperature (SST) anomalies, although other stress factors also can cause small-scale bleaching. The term bleaching hotspot has been coined to describe SST anomalies that approximate or exceed by $1.0^{\circ} \mathrm{C}$ or more the SST expected climatologically during the warmest month of the year as seen from NOAA's satellitederived observations (portrayed on monthly ocean features analysis maps [Goreau \& Hayes 1994] or NOAA's new, twice-weekly Bleaching Hotspot Chart [Strong et al. 1997; Goreau et al. 1997]). Many areas of the tropical oceans were influenced by unprecedented elevations in sea surface temperature during 1998 due to a severe El Nino Southern Oscillation (ENSO), and the Indian Ocean's 11-year oscillation, superimposed on a recently noted warming over the northern hemisphere tropics (Strong et al. 1997).

Maps showing the distribution of maximum monthly temperature anomalies based on satellite-derived sea surface temperatures during 1998 showed sea surface temperatures more than $0.9^{\circ} \mathrm{C}$ above normal in the warmest month (Figs. la-d, yellow and orange areas on the maps). Coral bleaching events are represented by points on the map; these reports are, for the most part, unpublished. Hence, reference to researchers (Appendix) throughout this paper reflect personal communications of unpublished data and are indicated by name alone in parentheses. A handful of coral bleaching reports came from locations $\bullet$ where these temperatures were between 0.7 and $0.9^{\circ} \mathrm{C}$ above normal (denoted in Fig. 1 by blue); however, in many of these cases, in situ measurements showed that water temperatures were in fact warmer than those observed from satellite data (for example in the Andaman Islands, Ravindran et al. 1999). There are several explanations for these observed differences. For example, some areas were too small to be resolved by satellite infrared thermal imagery; these include lagoons behind reefs where circulation was cut off by extreme low tides and small or narrowly distributed reefs. Furthermore, small clouds that are typical around high islands during extremely strong, smallscale thunderstorm activities during unusually warm periods may bias satellite measurements. Our analyses of temperature records of individual 
sites shows that many corals remained above bleaching thresholds for up to 5 months in the Indian Ocean and East Pacific, several months in areas of the West Pacific, and only for one or 2 months in the Caribbean.

Bleaching reports plotted on the maps (Fig. 1) are primarily from longterm observers who assessed the reefs both before and after the bleaching events, followed the event for a time period adequate to assess mortality related to bleaching, and made quantitative assessments before and after comparisons (Table 1). In addition there were many other reports by visiting divers (Wilkinson 1998; Hodgson 1999; Wilkinson et al. 1999) made during the peak of the bleaching. These reports produce high estimates for bleaching but low estimates for bleaching mortality. These observations were typically made near the peak of bleaching, when it was most obvious, but mortality often peaks several months after bleaching. Further uncertainty is introduced into these reports because observers often are not familiar with the reefs beforehand or with the annual cycle of coral pigmentation and therefore cannot distinguish between recent bleaching mortality and previously dead corals killed by other factors. For example, early reports compiled before the end of the bleaching event concluded that bleaching was widespread but "patchy," of uncertain origin, and that coral mortality was relatively minor in many places with large-scale impacts limited to the Indian Ocean.

\section{Distribution and Timing of Indian Ocean Coral Bleaching}

In the Indian Ocean, the area for which water temperatures passed coral bleaching thresholds was the greatest on record. Because researchers across the Indian Ocean were alerted to hotspot conditions before or during bleaching, unusually complete records were obtained both geographically and temporally (Strong et al. 1998). The 1998 bleaching event was not the first, but it was far larger, more intense, and more prolonged than previous Indian Ocean bleaching events in 1987, 1988, 1991, and 1994 (T.G. et al., unpublished data). Figure la shows the locations of temperature anomalies and bleaching reports in the Indian Ocean during 1998. Areas affected included the entire African coastline, the Arabian coast except the northern Red Sea, and the high-diversity center of the island chain off southern India, including Lakshadweep, Maldives, and Chagos islands and atolls.

Bleaching reports began in the southernmost Indian Ocean reefs in late 1997 and reached a peak in the Southern Indian Ocean in February to April 1998. Bleaching conditions followed the warm, calm, low pressure monsoon InterTropical Convergence (ITCZ) conditions northward until bleaching was observed in the northern Indian Ocean between May and June of 1998 and July to September in the Persian Gulf and Red Sea.

Water temperatures during peak warming periods were frequently $1-2^{\circ} \mathrm{C}$ above long-term means and exceeded $30^{\circ} \mathrm{C}$ in areas with extensive bleaching. Even after the ITCZ moved on, and temperatures cooled, many of the corals remained bleached. Species with branching morphologies were most sensitive to bleaching and were the first to die, often within a month of peak temperatures. Mortality of the more resistant massive and encrusting forms lagged some months behind the branching corals, and many of these forms died in water as cool as $26^{\circ} \mathrm{C}$. 

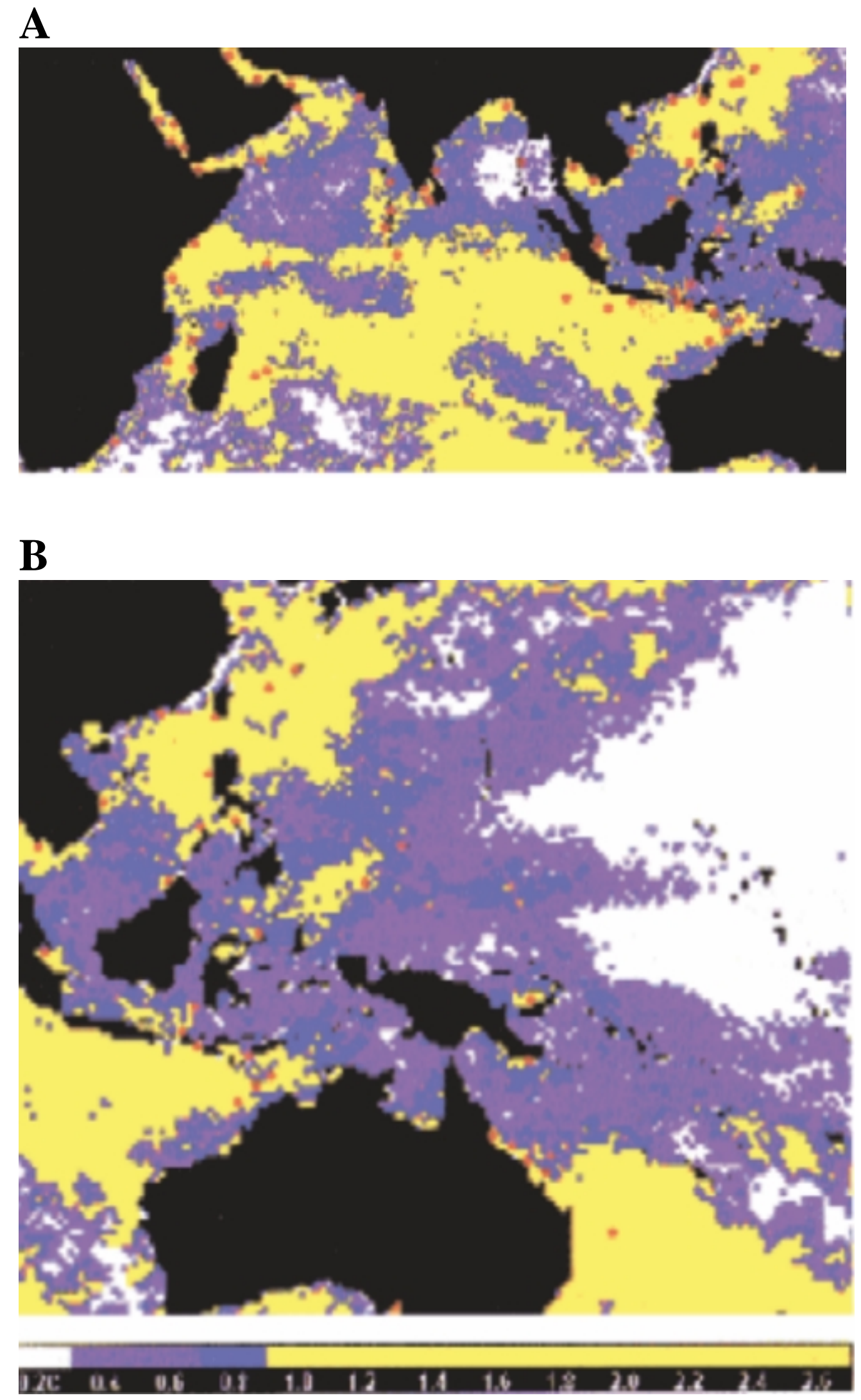


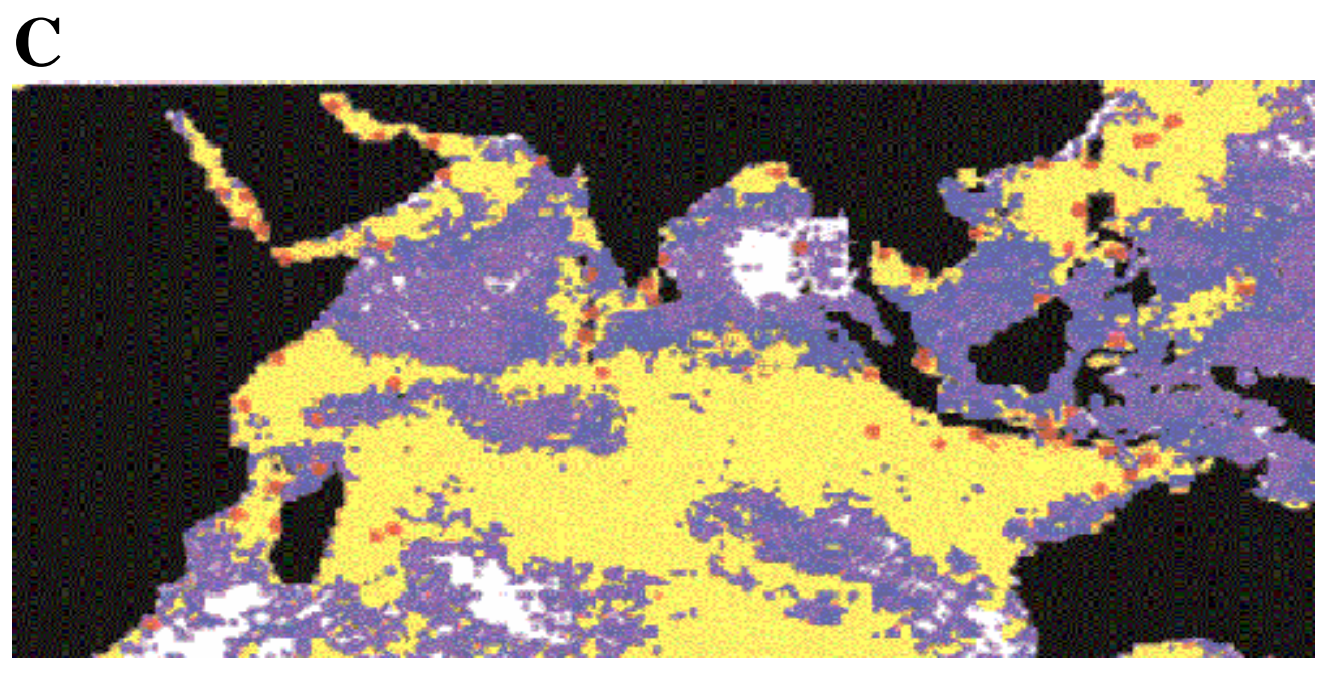

\section{D}
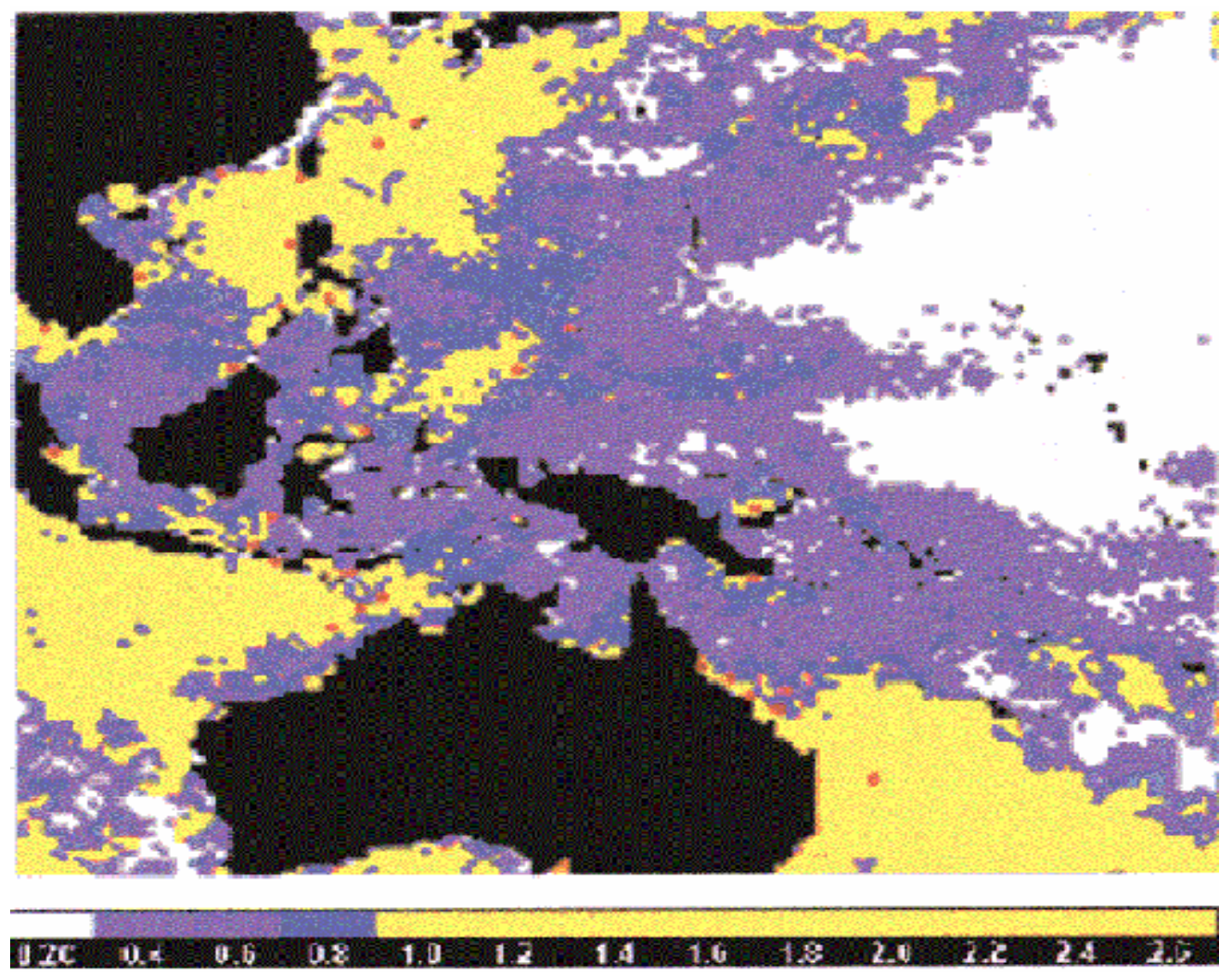

Figure 1. Maximum warm season temperature anomalies in the (a) Indian Ocean (b) West Pacific, (c) Et Pacific and Greater Atlantic, and (d) Caribbean. Areas shown in white are $<0.3^{\circ} \mathrm{C}$ above the long-term, seasonal maximum monthly average temperature, purple areas reached between 0.3 to $0.7^{\circ} \mathrm{C}$ above, blue areas reached between 0.7 and $0.9^{\circ} \mathrm{C}$ above, yellow areas reached from 0.9 to $1.3^{\circ} \mathrm{C}$ above, and orange areas reached more than $1.3^{\circ} \mathrm{C}$ above historic maximum averages. Bleaching reports are shown as red dots. Source of observations in Appendix. 


\section{Bleaching in the West Pacific}

Bleaching began in January in the Great Barrier Reef of Australia and Lord Howe Island (Berkelmans \& Oliver 1999). Bleaching was first attributed to the effects of freshwater because inshore and southern regions exhibited the greatest bleaching, and flooding had recently occurred in southern Queensland. This was later downplayed as a second-order effect when the bleaching was found to have extended away from river mouths following more closely with observed patterns of high sea surface temperatures as shown from satellite data. More bleaching nearer shore occurred because temperature anomalies did not rise as high in the northern and outer Great Barrier Reef (Fig. Ib). Mortality was severe in the inner and southern Great Barrier Reef, as high as 80-90 at a few inner reef sites, grading to very low mortality in northern and outer reefs (Berkelmans \& Oliver 1999; Done \& Fabricius unpublished data). Although portions of the Great Barrier Reef had undergone high temperature bleaching in 1982, 1987, 1988, 1991, and 1996, the 1998 event was the most extensive.

Bleaching began on the north and south sides of Papua, New Guinea in early 1998 (Cervino, Benjamin, Colin), and in January northern Ball temperatures remained above $30^{\circ} \mathrm{C}$ for 5 months. The area of hot water affecting southern Sumatra, Java, Bali, Lombok, and Timor was largely due to spillover of the large East Indian Ocean hotspot, which experienced only limited penetration into the central Indonesian seas. Many central Indonesian reefs were largely spared from severe bleaching, apparently because of high upwelling (Larry
Smith). Separate hotspots formed in the north of Indonesia, affecting reefs around Singapore, Northern Borneo, eastern Malaya, and Sulawesi (Fig. Ib). A large hotspot caused bleaching in the Gulf of Siam, Cambodia, and Vietnam, a small hotspot affected Palau and southern Philippines, and another large hotspot affected reefs of the South China Sea and East China Sea, including the northern Philippines, Hong Kong, Taiwan, Ishigaki, Iriomote, and Okinawa. Yap, at the edge of the hotspot, was less affected.

\section{Bleaching in the East Pacific}

Bleaching began in late 1997 with the onset of severe El Nino conditions across the East Pacific region from Cabo San Lucas to Ecuador, ineluding reefs of Pacific Mexico, Costa Rica, Panama, Colombia, and Ecuador (including the Galapagos). Bleaching also began in October 1997 in the far west from a hotspot at Christmas Island, Kiribati. The Society Islands, the Cook Islands, Samoa, Tonga, Tuvalu, and Hawaii were not affected by high temperatures or large-scale bleaching (Fig. Ic).

Areas of East Pacific that bleached were subjected to the hottest and most extensive hotspots on record. Yet mortality was relatively low because most of the coral reefs had recovered from severe bleaching mortality following hotspots in 1983, 1987, 1992, 1993, and 1997. Reefs off the Panamanian Pacific island of Coiba, which had been relatively unscathed in earlier events, were devastated in 1998. East Pacific reefs will have little chance to recover unless repeated bleaching episodes stop. The entire East Pacific coral reef region has been repeatedly devastated by bleaching events, and the likeli- 
hood of endemic species extinctions,

if not of total loss of reef frame-

works, is high (Glynn 1988, 1993)

\section{Bleaching in the Caribbean}

Typically, reports indicate that $60-$ 80 of all colonies at bleached Caribbean sites were affected (Fig. Id). Virtually every species of reef-building stony coral was affected. Fire corals, soft corals, and sponges were also bleached. Anomalous SSTs were responsible for mass coral reef bleaching that began during the warmest months of the year. In the Caribbean/North Atlantic, these anomalies peaked during August and September 1998 and persisted through
November. Although the hotspot areas of the Caribbean were similar in extent to the severe bleaching events of 1987, 1990, and 1995, they were primarily located over the deep water areas of the central and southern Caribbean where there are few reefs and a fringe of cooler water protects many of the islands

(Fig.Id). Belize and Cayman reported the worst bleaching ever recorded, and the effects are likely to be particularly severe due to subsequent destruction of the area's reefs by Hurricane Mitch (Mumby, 1999). Bleaching in Mexico was, in contrast, brief and recovery was rapid.

Table 1. Observations on the percentage of corals that were bleached and the subsequent mortality.

\begin{tabular}{|c|c|c|c|c|c|}
\hline Country & Site & Corali & over & $\begin{array}{l}\text { Mortality } \\
\text { "/v/estimate }\end{array}$ & Source* \\
\hline & & before bleaching & after bleaching & & \\
\hline South Africa & Sondwana & 62 & 72 & none & Samway \\
\hline Mozambique & not determined & & not determined & $20-80$ & Schleyer \\
\hline \multirow[t]{2}{*}{ Madagascar } & Masoala & 38 & 28 & 26 & McClanahan \\
\hline & & & & & and Obura \\
\hline Reunion & Fringing Reef & $30-50$ & not determined & slight & Nairn \\
\hline \multirow[t]{2}{*}{ Zanzibar } & Chumbe Island & $20-30$ & 63 & slight & McClanahan \\
\hline & & & & & \& Obura \\
\hline \multirow[t]{2}{*}{ Kenya } & Marine Protected & 40 & 11 & 73 & McClanahan \\
\hline & Area 1 & & & & \\
\hline Kenya & Unprotected Area 1 & 21 & 11 & 48 & McClanahan \\
\hline Qatar & Arabian Gulf & 90 & 1 & 99 & Sheppard \\
\hline India & Gulf of Kutch & 11 & 12 & not determined & Arthur \\
\hline India & Gulf of Mannar & 89 & 34 & not determined & Arthur \\
\hline India & Lakshadweep Islands & 37 & 8 & 78 & Arthur \\
\hline Sri Lanka & NE coast & not determined & not determined & none & Rajasunya \\
\hline Sri Lanka & SW coast & $75-100$ & not determined & 80 & Rajasuriya \\
\hline Maldives & North Male & 100 & 45 & 93 & dark \\
\hline Maldives & Bodhufinolhu & 36 & 16 & 56 & Sluka \\
\hline Maldives & South Male & 60 & 11 & 82 & McClanahan \\
\hline Maldives & Mulaku & 60 & 13 & 78 & McClanahan \\
\hline Maldives & Felidu & 60 & 6 & 90 & McClanahan \\
\hline Maldives & Ihuru & not determined & not determined & $95-99$ & Goreau \& Hilbertz \\
\hline Seychelles & Amirantes & $40-90$ & $7-47$ & 75 & Teleki \\
\hline Seychelles & 25 sites & not determined & not determined & $70-99$ & Goreau \\
\hline Chaeos & seaward reefs & $50-70$ & 0 to 25 & $80-90$ & Sheppard \\
\hline Chaeos & lagoon reefs & $50-90$ & 10 & $20-80$ & Sheppard \\
\hline \multicolumn{2}{|l|}{ Western Australia } & $40-60$ & 10 & $75-83$ & Heyward \\
\hline Okinawa & & 70 & 10 & 73 & Loya et al. \\
\hline
\end{tabular}


The lack of hurricane activity during the early summer allowed SSTs to climb; this elevation in SSTs was followed by three hurricanes, Bonnie (19-30 August), Georges (15 September - 1 October), and Mitch (24 November - 1 December). These hurricanes brought cold and deep water to the surface, produced heavy rainfall, and limited the duration of anomalous temperature exposures to coral reefs along their respective paths. For example, within 2 days of the passage of Hurricane Bonnie, sea temperatures in the Bahamas fell by $2.0^{\circ} \mathrm{C}$. Hurricanes resulted in extensive breakage of branching coral species throughout the region, -where branching species, such usAcropora cervicornis, had yet to recover from a devastating disease in the mid-1980s (Aronson \& Precht 1997; Goreau et al. 1998).

In previous years, Caribbean bleaching episodes were most evident in the northern sectors. The Cayman Islands, Jamaica, Cuba, the Bahamas, and Mexico were severely affected by bleaching in 1987, 1990, and 1995. In 1995 the barrier reef of Belize experienced mass bleaching for the first time (McField 1999). In 1998, however, southern sectors were most severely influenced. This shift may be due to the hurricanes tracking through the northern Caribbean sectors in 1998 .

\section{Bleaching in the Greater Atlantic}

Bleaching was reported in the northern and western Bahamas near Andros and New Providence and in Bermuda. Bleaching took place in the north-east of Brazil and in a small hotspot at the extreme southern fringe of Atlantic corals in Brazil. Bleaching took place in the eastern Mediterranean coast of Israel, affect- ing the naturalized introduced species Oculina patagonica. Hotspots also affected the Cape Verde Islands and the islands of the Gulf of Guinea (Fig. Ic), but no bleaching reports were available from these areas.

\section{Coral Mortality}

Across the Indian Ocean bleaching was correlated with high coral mortality (Table 1). Mortalities generally ranged from 70-99, with estimates around 90 most common across the region. Researchers reported that virtually all species in the genera Acropora, Seriatopora, Stylophora, Millepora, and Pocillopora were killed over large regions. Table 1 presents a partial list of mortality estimates for the aggregate coral cover. Low mortality was noted 10

Issues in International Conservation only in South Africa, where the reefs are deep and species poor, in Reunion and Gulf of Kutch, where corals are subjected to high sedimentation stress, and inside the reef lagoons of Mauritius, which are affected by high sedimentation and high fertilizer and sewage runoff.

Extremely high coral mortality was noted from areas of the Saudi Arabian Red Sea (Fadlallah, Devantier, Sheppard), Socotra (Devantier), Comoros (Thomassin), Sri Lanka (Ekaratne, Weerakkoddy, Rajasuriya), Lakshadweep (Raghukumar, Ravindran, Arthur), Chagos (Sheppard), and the reefs of Western Australia (Luke Smith, Heyward). Repeated photographic censuses around an entire Maldivian island found approximately 99 coral mortality (Goreau, Hilbertz, Azeez Hakeem). Other surveys of other Maldivian islands and atolls indicate nearly as high mortality (Clarke \& McClanahan, unpublished data). Line 
transects filmed before, during, and after bleaching in more than 20 reef sites around the high islands of the Seychelles showed mortality ranging from 70-99, averaging around 90 (Goreau 1998a, 1998\&). The highest mortality was observed in reefs with highest coral cover and the lowest mortality in the most stressed habitats (Goreau 1998o, 1998\&, and 1998c).

Extremely severe mortality was found in the reefs of Western Australia, including Scott, Ashmore, and Seringapatnam reefs, with near total mortality (Luke Smith). Heyward found 75 mortality on three Western Australian reefs. Severe coral mortality of up to 90 , with near total mortality of branching corals, was also reported for Palau (Colin, Idechong, Bruno), Northern and Central Philippines (Alino, Wegmann), Okinawa (Yamazoto, Loya), Iriomote (Van Woesik), Ishigaki (Van Woesik), and Vietnam (Tuan). Mortality also appears to have been severe in the Gulf of Thailand, Cambodia, and Taiwan. Palau, which had never before had a severe bleaching event, lost most branching and plate corals (Colin, Idechong, Bruno). Up to 90 of branching coral died in areas of the inner and southern Great Barrier Reef (Berkelmans \& Oliver 1999); however, only Acropora in the 3- to 5-m depths was severely affected (90 mortality). Other branching corals (Porites) and corals that were deeper $(>5 \mathrm{~m})$ had high survival rates of all forms. Much milder bleaching was seen in Yap, at the edge of the hotspot, mainly inside the lagoon (Romano) but was not reported from islands to the north or east that lay outside the hotspot.

Mortality rates in Indonesia were around 50 in Bali (Goreau), but lower in islands to the east (Larry
Smith) and in Sulawesi (Harahap, Erdmann, Hoeksma). Lower mortality -was found at Rowley Shoals and Houtman-Abrolhos that were located in small, cooler areas of water (Done). Lower mortality was also found in very turbid waters in the Gulf of Kutch (Arthur), Southwestern Sri Lanka (Weerakkody), Mahe (Goreau WSa, 1998\&), and inside the lagoon ofAlfonse atoll (Goreau 1998c). Some areas affected by strong upwelling also showed lower mortality, such as the outer reefs ofAlfonse, St. Francois, and Bijoutier atolls (Goreau 1998c) and certain locations in the Maldives (Kahleel) and Western Zanzibar (Reidemiller). In many of the reported cases upwelling episodes and high turbidity appear to have protected corals, to some degree, from severe mortality.

Overall, coral mortality following bleaching was extensive except for the extreme southernmost fringe, the cooler waters of the Andaman Sea, off Burma, western Thailand, western Malaya, and northern Sumatra, and the northernmost Red Sea, including Hurghada and Sinai. Although being surrounded by cooler water, reefs in the Andaman Islands were severely bleached, and temperatures within reef waters reached 30-31 ${ }^{\circ} \mathrm{C}$ (Ravindran et al. 1999), but the area affected apparently was too small to show on satellite images. Here the time interval for bleaching may have been shorter than 1 month: hotspots did not show up in the twice-weekly NOAA charts. The IndoPacific species most affected by mortality were the most abundant, fastest growing, and fastest recruiting branching and table coral species. These are the most important coral species in terms of providing shelter for fish and in breaking waves and protecting the coastline.

The overwhelming majority of sur- 
vivors in severely bleached IndoPacific reefs were massive corals in the family Poritidae, followed by the Favidae, but many or most of these showed partial mortality, often with only small portions surviving. Many post-bleaching field surveys in the Indian Ocean found that reefs throughout the region presently have only around 10 or less live coral cover. Previous studies suggest that some loss in coral cover in some of the remote atolls took place during the 1987/88 event (Allison 1995; Sheppard 2000«). The 1997/1998 event, however, was particularly devastating to many species (T.M., unpublished data).

In terms of overall mortality, the effects of 1998 were greater than any previous year because of the unprecedented size of the Indian Ocean, Northwest Pacific, and Southwest Pacific hotspots and the high coral mortality that followed. Fortunately, however, the limited impact in the central Indonesia species coral reef diversity center in the Banda and Flores Seas may allow transport of coral larvae to nearby damaged regions. Although recovery may be expected to be slow even in areas undamaged by human activities, there is some hope of eventual recovery only if the central Indonesian area can be protected from further damage by high temperatures, dynamite, poisons, sedimentation, and nutrient buildup. Areas escaping thermal damage in 1998 in the West Pacific include the Marianas, most of Micronesia, Melanesia, and most of Polynesia except the Tuamotos.

Mortality from bleaching in the Caribbean was fairly minor compared Issues in International Conservation with the Indian and Pacific Oceans. Estimated losses of coral cover from mortality in the Caribbean due to the 1998 bleaching event do not exceed 5-10, although higher values up to 25 have been found in patch reefs of Glovers Reef Atoll (McClanahan, McField, and Huitric). Nevertheless, coral cover across the region is continuing to decline rapidly as the result of algae overgrowth and coral diseases (McClanahan \& Muthiga 1998; Shulman \& Robertson 1997; Goreau et al. 1998; Jaap et al. 1999). Diseases, including white band and yellow band, were widespread in distribution throughout the region before the 1998 bleaching episode. Although diseases are continuing to increase, there seems to be little consensus on the relation of disease to coral bleaching (Goreau et al. 1998; L. Richardson, personal communication). Some experimental evidence from a Mediterranean coral suggests a causal link between infections and bleaching (Kushmaro et al. 1996).

In strong contrast to the IndoPacific, where Acropora species often have been observed among the first to bleach and die, the Caribbean Acropora were among the last to bleach (McField 1999). Although recovery of Caribbean species generally has been high following bleaching there are clear differences between species in terms of both duration of recovery and mortality. Montastrea cavemosa, Siderastrea siderea, and Montastrea annularis are usually among the slowest to recover and appear to have their growth depressed for the longest intervals, often showing partial mortality around colony edges after prolonged bleaching events. This makes them more susceptible to reduced recovery intervals between bleaching events. The deep-water Agaricia species show fairly high mortality, but the shallow-water species, especially A. 
tenuifolia, are less affected. Millepora complanata and M. alcicomis show high mortality during severe events even though they are among the first to recover from mild bleaching events. Differential mortality and susceptibility to prolonged recovery intervals would be expected to eventually cause noticeable changes in Caribbean reef species composition following repeated bleaching even without severe mortality.

\section{Potential for Ecosystem Recovery}

In most observed locations, coral killed by bleaching was rapidly overgrown by filamentous algae. Waters turned green in many places, apparently fertilized by nutrients from the decomposing corals. The phytoplankton blooms and filamentous algae overgrowth on dead corals usually disappeared in a few months. Following this, in areas of high nutrient input and with low fishing pressure (and therefore higher fish abundance) an algal turf was commonly observed. In areas with low nutrient inputs, encrusting calcareous red algae were more common. In locations with strong nutrient inputs (near land with high surface runoff or upwelling areas) and where fishing effort is high, die-offs of phytoplankton blooms and filamentous algae were followed by fleshy macrophytic algae overgrowth. In some areas of the Indian Ocean and Indonesia with high nutrient inputs, dead corals were overgrown by ascidians or sponges. Areas subject to nutrient inputs will probably remain algae dominated even if new coral recruitment is high. Recovery most likely will be on cleaner, encrusting, coralline algae-dominated areas when and if coral recruitment resumes.

The major surviving corals in IndoPacific reefs, the large head Porites species, became dominant corals in many reefs after bleaching because of their high survival; a further concern is that most of these corals are dying back at a few centimeters a month from Porites line disease (Ravindran et al. 1999). This has been noted in Seychelles (Goreau), Maldives (Goreau \& Hilbertz), Sri Lanka (Weerakkody), and India (Ravindran, Raghukumar), but the distribution of the disease spans the Indo-Pacific (T.G., unpublished data). Multiple catastrophes (higher SSTs, more pronounced ENSOs, and disease) •will slow recovery to significantly longer than the decade recovery time typical of catastrophic local damage (such as from hurricanes or ship groundings) in areas with recruitment from nearby undamaged areas.

Recovery of corals depends on future temperature regimes and the ability of species, taxonomic groups, and ecological communities to adapt to external environmental and internal ecological changes. The Kenyan monitoring study suggests that the ecological outcome of coral mortality depends on the amount of mortality interacting with the levels of herbivory and nutrient inputs. Reefs -with low herbivory and high coral mortality experienced the greatest ecological changes, with those reefs customarily becoming dominated with large, fleshy algae (T.M., unpublished data). Large, erect, fleshy algae have been shown to suppress coral growth and recovery (Tanner 1995) as well as the abundance and diversity of fishes (McClanahan et al. 1999).

Even remote reefs with high levels of herbivory had increased erect algal and sponge cover (Sheppard 2000a; T.M., unpublished data). Preliminary coral recruitment studies have found that some of the reefs with high levels of herbivory also have low levels 
of coral recruitment. It is possible that predators of corals (high level of herbivory) are now feeding on small coral recruits due to the lack of older corals to feed on (McClanahan \& Dusek, unpublished data).

Because it appears that most of the entire Indian Ocean was affected by high bleaching mortality in 1998, there is likely to be minimal recruitment of branching corals in the next few years because virtually every potential source area, with sexually mature branching coral populations, was affected by catastrophic mortality. So great is the observed mortality that local, if not regional, extinction of many species of branching corals is likely. Extinction may have extended to regional endemics because the entire central area of coral reef species diversity was affected along with most outlying areas. Recovery is likely to be prolonged due to lack of enough mature corals to provide new recruits and is even less likely in areas that are anthropogenically perturbed. If bleaching events recur in the coming years, even the cleanest and most remote reef areas may fail to recover.

Despite the severe coral mortality that affected large areas of the Western and Eastern Pacific, eventual recovery is possible because coral larvae may, in fact, be supplied from remote, unaffected source regions by currents. Large areas of the central Pacific and central Indonesia escaped damage from bleaching in 1998 as did some localized areas affected by sediment stress and/or upwelling. Ironically these stressed areas may be the larval source for the recovering reefs; unfortunately, these stressed environments do not have the full diversity of species. Many scientists, however, are concerned that continued global warming would cause hotspots to become more frequent, widespread, and intense. Such a scenario would only cause more severe bleaching (Goreau \& Hayes 1994; Hoegh-Guldberg 1999) that could eventually lead to large-scale, mass extinction of many coral' reef species. Even in the best-case scenarios it is expected that recovery will be slow, particularly in areas with other stressful influences, such as sewage and fertilizer nutrients, sedimentation, and overfishing.

\section{Climate Change: El Niiio, the Indian Ocean Oscillation, and Global Warming}

Although the 1998 bleaching -was widely attributed to El Nino, recent work shows that the Indian Ocean may be even more influenced by an internally generated climatic oscillation of 11-12 years that is not always in phase with El Nino events, but which happened to coincide with them in 1998 (Webster et al. 1999; Saji et al. 1999). Long-term records of Indian Ocean climate oscillations recorded from coral cores show irregular cycles that often differ, but always incorporate ENSO cycles (Cole et al., 1999). In the Indian Ocean, the $1997 / 1998$ ENSO was the strongest recorded since 1877/1878 (McPhaden 1999). In addition, recently climatologists have been uncovering more information on another important contributor to the climate system that operates primarily over the Pacific Ocean, but undoubtedly has an influence on the adjoining Indian Ocean-the Pacific Decadal Oscillation (Mantua et al. 1997). Having a period of several decades, this climate oscillator also may have been at its peak at this time, helping to further boost tropical SSTs especially north of the equator in the $\mathrm{Pa}$ - 
cific and Indian Oceans.

Indian Ocean temperatures appear to oscillate between 3.5 and 5.3 years periods, with the shorter cycle dominant before the 1920s and after the 1960s and the longer cycle dominant in the interim (Charles et al. 1997). Both cycles are contained within a stronger cycle of 11.8 to 12.3 years driven by the Asian monsoon system. Therefore, the strongest warming events will occur when decadal and ENSO oscillations are temporarily in phase, as apparently happened in 1998. A number of recent (150- to 200-year) temperature record studies, based on the isotopic ratio of oxygen in coral cores, found strong parallels between Indian Ocean and Pacific oscillations, but with occasional diversions from this association. East African temperature patterns (Cole et al., 1999) are more strongly related to ENSO events than western Australia (Kuhnert et al. 1999) or Seychelles sites (Charles et al. 1997).

The patterns of bleaching seen in 1998, although strongly influenced by El Nino teleconnections, appear to have differed from it in many significant regards, especially the severe bleaching in most areas of Australia, Indonesia, the Philippines, and the South China Sea, which normally cool down during El Nino events. If ENSO were the only factor involved there might be reasons for complacency because the $1998 \mathrm{El}$ Nino could have been the most severe ENSO event of the last millennium, making bleaching of such severity unlikely to recur except on a scale much longer than reef recovery time. The factor that continues to gradually worsen the situation, of course, is global warming. The trends in SST over the tropics during the last 15 years are remarkable, espe- cially over the sites north of the equator (Strong et al. 1997) (some locations have seen increases based on satellite-derived SST measurements of nearly $0.05^{\circ} \mathrm{C}$ per year). The patterns of SST changes that the oceans have been showing since 1984 do not fit present global change models that predict larger increases at higher latitudes — not the latitude of $5^{\circ} \mathrm{N}$ (ocean average).

The death of thousand-year-old coral colonies during 1998 (Goreau 1998\&; Hodgson 1999), all of which had survived hundreds of previous El Nino events, highlights how exceptional 1998 was. If global warming is raising the baseline on which regional ENSO fluctuations occur (Williams \& Bunkley-Williams 1990), then global warming needs to be considered an important ingredient in bleaching. If true, then all reef areas that are warming gradually will shift from an apparent ENSO, dipole, quasi-decadal periodicity (Huppert \& Stone 1998) to events that become biennial or annual (T.G. et al., unpublished data; Hoegh-Guldberg, 1999).

It is feared that global warming's effects will cause hotspots to become more frequent, more intense, and more widespread in the decades ahead (Goreau \& Hayes 1994). Bleaching mortality will become much more severe unless corals are capable of physiological acclimation.

Corals have lived successfully in warmer and colder temperatures in the past. For example, around 2 million years ago massive coral extinctions at the start of the ice ages (Budd \& Johnson 1997) wiped out the most high-temperature-tolerant species, which were replaced with new low-temperature tolerant coral species that are the ancestors of modern corals. The real concern is that adaptations that would allow 
corals and their symbiotic algae to acquire high temperature tolerance that they now apparently lack will take more time than that allowed for by the present rate of warming.

\section{Conservation Implications}

The largest and longest field study in the western Indian Ocean, which has a number of study sites in and out of marine protected areas in Kenya, found that nearly all reefs were reduced to around 10 coral cover, despite the fact that protected areas had 45 cover and unprotected areas had 25 cover before the bleaching (T.M., unpublished data). The protected areas contained many of the sensitive and more delicate species with branching morphologies, indicating that protection from resource extraction, changes in the food web, or destructive gear (McClanahan \& Mutere 1994) was ineffective in preventing bleaching-related mortality. This suggests, as above, that already degraded or stressed reefs may be the least likely to show the full effects of bleaching because populations of sensitive species may already be reduced greatly.

A troubling aspect of the high mortality observed in the Maldives and surrounding reef regions is that these islands are the center of coral diversity in the Indian Ocean. This area has the region's warmest water temperatures, which was originally hypothesized as the cause for this high diversity (Rosen 1971; Sheppard 2000\&). A fairly extensive postbleaching survey of Maldivian corals in three atolls found, however, that at least a dozen of the branching species went locally extinct since surveys in the early 1960s (T.M., unpublished data). Water temperatures are widely thought to promote coral diversity, but beyond some threshold, probably just above $30^{\circ} \mathrm{C}$, the numbers of species may drop as high-temperature-sensitive species are lost. This upper temperature limit was first derived by A. Mayor (1918) and Yonge and Nicholls (1931), who found that corals from the Great Barrier Reef, the Torres Straits, and Florida bleached and died above these levels and showed no capability to adapt to higher temperatures. This was confirmed by the inability of corals to recolonize areas with thermal effluent discharges (Jokiel \& Coles 1977) and from experimental temperature manipulation studies (Glynn \& D'Croz 1990; Berkelmans \&Willis 1999).

Coral mortality also has profound effects on many other reef organisms. Comparison of video transects taken before and after bleaching in the Seychelles (Goreau) and Maldives (Goreau, Hilbertz, Azeez Hakeem) found that invertebrate populations appeared to be severely depleted following bleaching, with many previously noticeable groups of fauna disappearing or greatly reduced including Acanthaster planci, the coral-eating crown-of-thorns starfish. The few surviving A. planci that could be found were eating coral species that they normally do not eat, especially Porites.

Fish populations are reported to have declined, but few quantitative studies have been completed. Species dependent on coral—such as butterflyfish and those that shelter in coral (some damselfish and Anthiads) — are expected to decline. In many bleached areas, fish populations have become dominated by parrotflsh and surgeonfish grazing the algae overgrowing dead coral. Further studies are required to determine the extent of the problem for 
fishes. Reef fisheries studies are also rare, but a continuous study from Kenya found no immediate or prolonged drop in fish catches after the bleaching. This is not entirely surprising as catch from these degraded reefs is often of species that are not coral dependent, such as seagrassfeeding rabbitfish and parrotfish or planktonic species.

Intact branching corals are often strongly correlated with fish and invertebrate population sizes and diversity. Immediately after bleaching of Indian Ocean reefs the structure of the branching and plate corals was intact, but with the subsequent cold monsoon, these started to break apart. This loss of reef structure is likely to affect species dependent on this structure, reduce shoreline protection, and increase coastal erosion. Coastal erosion is an especially serious concern for the low-lying islands of the Maldives, Lakshadweep, Chagos, and the atoll islands of western Seychelles and northern Mauritius. That the incidence of cyclones in the Indian Ocean and Pacific is increasing (Chu \& Wang 1997) adds further cause for concern.

Much funding is currently being put into the establishment of marine protected areas. While desirable for many reasons, such as the control of overfishing and controlling tourist and anchor damage, this form of management is unable to protect reefs from high temperatures, coral diseases, or nonpoint sewage and fertilizers. Reliance on protected areas thus cannot save coral reefs unless the root causes of coral mortality are also stopped. Any strategy of protected areas that does not control these threats will probably not protect coral reef species, the ecosystem, and its processes.

In essence, this global bleaching event indicates that coral reefs are endangered habitats and management must shift to include the level of the ecosystem and global processes, rather than remaining focused only on individual species and local management. If the Convention on Biological Diversity and the Framework Convention on Climate

Change are to meet their own goals of protecting the most species-rich and economically valuable tropical marine ecosystems, a number of actions will need to be taken at both local and global levels. Clearly, reversing global warming is critical, although exceedingly difficult politically and economically. We must recognize that current goals may be inadequate. Even if there were an immediate reduction of 50 in the use of fossil fuels, the existing momentum of global warming is such that changes at a scale likely to improve persistence of coral reef systems will take a number of years. At a local level, there must be a moratorium on the harvesting of wild branching corals. Perhaps it is also time to preserve and propagate rare branching species in aquariums. Funding is also needed to determine the full ecological impact of this bleaching event on coral reef ecosystems. For instance, we must determine their resilience, develop and amplify methods of restoring damaged coral reef habitat, and study the effect of large-scale bleaching and mortality on ecological services provided by coral reef systems such as fisheries.

\section{Tom Goreau}

Global Coral Reef Alliance 


\section{Tim McClanahan}

The Wildlife Conservation Society, P.O. Box 99470, Mombasa, Kenya

\section{Ray Hayes}

Howard University, Washington, D.C. 20059, Association of Marine Laboratories of the Caribbean

\section{Al Strong}

National Oceanic and Atmospheric

Administration/

NESDIS, Camp Springs, Maryland, 20746, U.S.A.

\section{Literature Cited}

Allison, W. R. 1995. Changes in the Maldivian reef system. Coastal Management in Tropical Asia 4:6-8.

Aronson, R. B., and W. F. Precht. 1997. Stasis, biological disturbance, and community structure of a Holocene coral reef. Paleobiology 23:336-346.

Berkelmans, R., andj. K. Oliver. 1999. Large scale bleaching of corals on the Great Barrier Reef. Coral Reefs 18:55-60.

Berkelmans, R., and B. L. Willis. 1999. Seasonal and local spatial patterns in the upper thermal limits of corals on the inshore central Great Barrier Reef. Coral Reefs 18: 219-228.

Budd, A. F., and K. G. Johnson. 1997. Coral reef community dynamics over 8 million years of evolutionary time: stasis and turnover. Proceedings of the 8th International Coral Reef Symposium 1:423-428.

Charles, C. D., D. E. Hunter, and R. D. Fairbanks. 1997. Interaction between the ENSO and the Asian monsoon in a coral record of tropical climate. Science 277: 925-928.

Chu, P.-S., and J.-B. Wang. 1997. Recent climate change in the tropical Western Pacific and Indian Ocean regions as detected by outgoing longwave radiation records. Journal of Climate 10:636-646.
Cole, J., R. Dunbar, T. McClanahan, and N. Muthiga. 1999. Tropical Pacific forcing of decadal variability in SST in the western Indian Ocean. Science: in press.

Glynn, P. W. 1988. El Nino warming, coral mortality and reef framework destruction by echinoid bioerosion in the Eastern Pacific. Galaxea 7:129-160.

Glynn, P. W. 1991. Coral bleaching in the 1980s and possible connections with global warming. Trends in Ecology and Evolution 6:175-179.

Glynn, P. W. 1993. Coral reef bleaching-ecological perspectives. Coral Reefs 12:1-17.

Glynn, P. W., and L. D'Croz. 1990. Experimental evidence for high temperature stress as the cause of El Nino coincident coral mortality. Coral Reefs 8:181-191.

Goreau, T.J.,J. Cervino, M. Goreau, R. Hayes, M. Hayes, L. Richardson, G. Smith, K. DeMeyer, I. Nagelkerken, J. Garzon-Ferreira, D. Gil, G. Garrison, E. H. Williams, L. Bunkley-Williams, C. Quirolo, K. Patterson, J. W. Porter, and K. Porter. 1998. Rapid spread of diseases in Caribbean coral reefs. Rev Biol. Trop. 46 Supl 5:157-171.

Goreau, T. J., R. Hayes, and A. Strong. 1997. Tracking South Pacific bleaching by satellite and field observations. Proceedings of the Eighth International Coral Reef Symposium 2:1491-1494.

Goreau, T. J., R. L. Haves, J. W. Clarke, D. J. Basta, and C. N. Robertson. 1993. Elevated sea surface temperatures correlate with Caribbean coral reef bleaching. Pages 225255 in R. Geyer, editor. A global warming forum: scientific, economic, and legal overview. CRC Press, Boca Raton, Florida.

Goreau, T. J., and R. L. Hayes. 1994. Coral bleaching and ocean "hotspots." Ambio 23:176-180.

Goreau, T.J., and R. L. Hayes. 1995. Coral reef bleaching in the South Central Pacific during 1994. Report to the U. S. Department of State, Washington, D.C. Available through

Global Coral Reef Alliance web site at http:// 
www.fas.harvard.edu/ goreau.

Goreau, T. J. 1998a. Coral bleaching in Seychelles: impacts and recommendations.

Report to the Seychelles Marine Park Authority. Available through Global Coral

Reef Alliance web site at http://www.fas. harvard .edu/ goreau.

Goreau, T. J. 1998\&. Coral recover\}' from bleaching in Seychelles, December, 1998. Report to the Seychelles Marine Park Authority. Available through Global Coral Reef Alliance web site at http://www. fas. harvard. edu/ goreau.

Goreau, T. J. 1998c. Coral recovery from bleaching in Alphonse and Bijoutier. Report to the Seychelles Marine Park Authority. Available through Global Coral Reef Alliance web site at http://www.fas.harvard.edu/ goreau.

Hodgson, G. 1999. A global assessment of human effects on coral reefs. Marine Pollution Bulletin 38:345-355.

Hoegh-Guldberg, 0. 1999. Coral bleaching, climate change, and the future of the world's coral reefs. Marine and Freshwater Research: in press.

Huppert, A., and L. Stone. 1998. Chaos in the Pacific's coral bleaching cycle. American Naturalist 152:447-459.

Jaap, W., P. Dustan, J. W. Porter, and J. L. Wheaton. 1999. Florida Keys National Marine Sanctuary water quality protection plan: coral reef and hard bottom monitoring project annual report. U.S. Environmental Protection Agency, Atlanta.

Jokiel, P., and S. Coles. 1977. Effect of tempera-

ture on the mortality and growth of Hawaiian reef corals. Marine Biology 43:201-208.

Jokiel, P., and S. Coles. 1990. Response of Hawaiian and other Indo-Pacific corals to elevated temperatures. Coral Reefs 8:155-162.

Kuhnert, H., et al. 1999. A 200-year coral stable oxygen isotope record from a high-latitude reef off Western Australia. Coral Reefs 18:1-12.

Kushmaro, A., Y. Loya, M. Fine, and E. Rosenberg. 1996. Bacterial infection and coral bleaching. Nature 380:396.
Mantua, N.J., S. R. Hare, Y. Zhang.J. M. Wallace,

and R. C. Francis. 1997. A Pacific Interdecadal Climate Oscillation with Impacts on Salmon Production. Bull. American Meteoro-

logical Society 78:1069-1079.

Mayor, A. C. 1918. Toxic effects due to high tem-

perature. Carnegie Institution of Washington Papers in Marine Biology 12:175-178.

McClanahan, T. R., and J. C. Mutere. 1994. Coral and sea urchin assemblage structure and interrelationships in Kenyan reef lagoons. Hydrobiologia 286:109-124.

McClanahan, T. R., and N. A. Muthiga. 1998. An ecological shift in a remote coral atoll of Belize over 25 years. Environmental Conservation 25:122-130.

McClanahan, T. R., V. Hendrick, M. J. Rodrigues, and N. V. C. Polunin. 1999. Varying responses of herbivorous and invertebrate-feeding fishes to macroalgal reduction on a coral reef. Coral Reefs 18:162.

McField, M. D. 1999. Coral response during and after mass bleaching in Belize. Bulletin of Marine Science 64:155-172.

McPhaden, M. J. 1999. Genesis and evolution of the 1997-98 El Nino. Science 283:950954.

Mumby, P. J. 1999. Bleaching and hurricane disturbances to populations of coral recruits in Belize. Marine Ecology Progress Series 190:27-35.

Munguia Vega, A., and H. Reyes Bonilla. 1999.

Cambios en la concentracion de clorofila a en colonias de Pocillopora verrucosa (Sceleractinia) durante un blanqueamiento coralino en el Golfo de California (1997). Revista de Biologia Tropical 47 (4): in press.

Ravindran, J., C. Raghukumar, and S. Raghukumar. 1999. Disease and stress-induced mortality of corals in Indian reefs and observations on bleaching of corals in the Andamans. Current Science (India) 76: 233-237.

Reaser, J. K., R. Pomerance, and P. 0. Thomas. 2000. Coral bleaching, coral mortal- 
ity, and global climate change. Conservation Biology: in press.

Rosen, B. 1971. The distribution of reef coral genera in the Indian Ocean. Symposium of the Zoological Society of London 28:263299.

Saji, N. H., B. N. Goswami, P. N. Vinayachandran, and T. Yamagata. 1999. A dipole mode in the tropical Indian Ocean. Nature 401:360-363.

Sheppard, C. R. C. 2000a. The Chagos Archipelago. Pages 445-470 in T. R. McClanahan, C. R. C. Sheppard, and D. 0. Obura, editors. Coral reefs of the Indian Ocean: their ecology and conservation. Oxford University Press, New York.

Sheppard, C. R. C. 2000\&. Coral reefs of the western Indian Ocean, an overview. Pages 3-38 in T. R. McClanahan, C. R. C. Sheppard, and D. 0. Obura, editors. Coral reefs of the Indian Ocean: their ecology and conservation. Oxford University Press, New York.

Shulman, M. J., and D. R. Robertson. 1997. Changes in the coral reef of San Bias, Caribbean Panama: 1983 to 1990 . Coral Reefs 15:231-236.

Strong. A., C. B. Barrientos, C. Duda, and J. Sapper. 1997. Improved satellite techniques for monitoring coral reef bleaching. Proceedings of the 8th International Coral Reef Symposium 2:1495-1498.

Strong, A., T. Goreau, and R. Hayes. 1998. Ocean hotspots and coral reef bleaching, January-July 1998. Reef Encounters 24: 20-22.

Tanner, J. E. 1995. Competition between scleractinian corals and macroalgae an experimental investigation of coral growth, survival and reproduction. Journal of Experimental Marine Biology and Ecology 190:151-168.

Webster, P. J., A. M. Moore, J. P. Loschnigg, and R. R. Leben. 1999. Coupled oceanatmosphere dynamics in the Indian Ocean during 1997-1998. Nature 401:356-360.

Wilkson, C. 0., editor. 1998. The status of the coral reefs of the world: 1998. Australian Institute of Marine Sciences, Global Coral Reef Monitoring Network, Townsville,
Queensland.

Wilkinson, C., 0. Linden, H. Cesar, G. Hodgson, J. Rubens, and A. E. Strong. 1999.

Ecological and socioeconomic impacts of 1998 coral mortality in the Indian Ocean: an ENSO impact and a warning of future change? Ambio 28:188-196.

Williams, E., and L. Bunkley-Williams. 1990.

The worldwide coral bleaching cycle and related sources of coral mortality. Atoll Research Bulletin 335:1-71.

Yonge, C. M., and A. G. Nicholls. 1931. Studies on the physiology of corals. Great Barrier Reef Expedition Scientific Papers 1: 135-211.

Appendix 1: Source of observations of coral reefs on

Fig. 1 and in Table 1.*

Indian Ocean

Sondwana, South Africa (Korrubel, Schleyer), Primeiras e Segundas, Mozambique (Rodrigues),

Comoros (Thomassin), Reunion (Thomassin, Nairn, Bigot), Mauritius (Fagoonee, Turner, Hassell, Wilson, Bheroo), Seychelles (Goreau, Souyave), Amir-antes (Teleki), Madagascar (McClanahan, Obura), Zanzibar, Pemba, and Tanganyika (Suleiman), Kenya (McClanahan, Muthiga, Obura), Djibouti, Yemen (Devantier, Abubakr), Eritrea (Peduli), Sudan (Ormond), Jedda, Saudi Arabia (Fadlallah), Socotra (Devantier), Jubail, Saudi Arabia (Devantier), Qatar (Wilson), Muscat, Oman (Wilson), Rann of Kutch, India (Arthur, Raghukumar), Lakshadweep, India (Raghukumar, Ravindran, Koya), Mandapam, India (Raghukumar), Tuticorin, India (Jeyabaskaran), Andamans (Ravindran), Sri Lanka (Ekaratne, Weerakkody, Rajasuriya), Maldives (Azeez Hakeem,

Naseer, Allison, Flueck), Chagos (Shepherd), St. Martins Island, Bangladesh (Khan), S.

Sumatra (Suharsono), Java (Suharsono, Hutomo, Moosa, Llewellyn), Bali (Goreau), Lombok (Haq), Timor (Larry Smith), Scott Reef (Luke Smith), Ashmore Reef (Luke Smith), Seringaptanam Reef (Luke Smith), Christmas Island (Done), Cocos-Keeling (Done).

West Pacific 
Singapore (Chou, Low, Koh), Northern Borneo (Baker), eastern Malaya (Oakley), Sulawesi (Larry Smith, Harahap, Erdmann, Hoeksma), Gulf of Siam (Chandler, Ohmann), Cambodia (Nelson, Monyneath), Vietnam (Tuan, Hodgson), Palau (Colin, Idechong, Bruno) northern (Alino, Gomez, Wegmann) and southern Philippines (Tacio), Hong Kong (Wong), Taiwan (Hsia), Ishigaki (Van Woesik), Iriomote (Van Woesik), and Okinawa (Yamazoto, Loya), Yap (Romano).

East Pacific

Pacific Mexico (Munguia Vega \& Reyes Bonilla 1999), Costa Rica (Cortes), Panama (Glynn,

Peralta, Eakin), Colombia (Garzon), Ecuador (Glynn) including the Galapagos (Wellington), Christmas Island, Kiribati (Teem), Tuamoto Islands (Chancerelle)

Atlantic bleaching northern and western Bahamas near Andros and New Providence (Houdret), Bermuda (Smith), Brazil (Kenji, Migotto); eastern Mediterranean coast of Israel, affecting the naturalized introduced species Oculina patagonica (Loya).

Caribbean

Belize (McField, McClanahan, Borneman, Ledesma). Cayman (Austin, Bush), Mexico (Iglesias Prieto, Perez), Florida (Porter, Quirolo, Jaap, Causey, Barimo), Bonaire (de Meyer), Curacao (Nagelkerken), Cuba (Alcolado), Barbados (Nurse), Puerto Rico (Williams, Weil, Bruckner), Virgin Islands (Battey, Garrison), Guadeloupe (Bouchon), Antigua (Derrick), Tobago (Young), Jamaica (Espeut), Panama (Tribaldos, Gonzalez Diaz), Costa Rica (Cortes),

Colombia (Garzon Ferreira), Venezuela (Weil). 